\title{
The Concrete Practice of College English Flipped Classroom Teaching Mode from the Perspective of Ecology
}

\author{
Jingjing Guan \\ Qiqihar Medical University, Qiqihar City, Heilongjiang Province, 161006, China
}

Key words: Educational ecology; Concrete practice; College English; Flipped classroom

\begin{abstract}
One of the core issues of educational ecology is the ecological balance of education. Using the principle of educational ecology to guide college English teaching and constructing an ecological college English flipped classroom model can improve the teaching effect of college English. Based on the author's learning and practical experience, this paper firstly explained the connotation and characteristics of educational ecology, and then the paper put forward the teaching mode of college English flipped classroom based on the theory of educational ecology with an example of the reading teaching.
\end{abstract}

\section{Introduction}

Classroom is the main place of college English teaching, which optimizes the teaching environment of college English, constructs a harmonious classroom atmosphere and establishes a good relationship between teachers and students. It is also an important issue in the reform of college English teaching. As an interdisciplinary subject developed from the interaction between education and ecology, educational ecology studies the relationship between the elements of the educational system and the interaction with the surrounding environment, which uses the whole and the developmental vision to explore the social ecosystem of "people - education environment". The combination of the educational ecology theory and the flipped classroom theory can provide some references for the innovation of college English.

\section{The Connotation and Characteristics of Educational Ecology}

Implications of educational ecology. The term "ecology" was firstly proposed by German biologist E.Haeckel. He believed that the study of the relationship between living organisms and their environment is ecology. After entering in $20^{\text {th }}$ Century, the ecological consciousness of human being is becoming more and more intense. The influence of ecology on linguistics, psychology and philosophy is becoming more and more prominent. The educational circles have begun to try to use the basic principles of ecology to study the education and teaching and explore the law of development of education. But it was not until 1976 that the concept of "educational ecology" was formally put forward by Cremin who is a famous educator in the United States. Educational ecology is the link between education and its ecological environment. It is a new subject with its relation and mechanism as the research object.

Characteristics of educational ecology. First, it is the equality of the main status. In the ecological classroom, teachers and students are the producers, consumers, and consumers of the knowledge in the ecosystem. As the construction of knowledge, students are the center of teaching activities and interact with teachers in an equal position. The teachers are no longer the sole control of the classroom discourse power, but they are the creator of the scene, the activities of the designer and the thinking inspiration. They are not only the student's learning partner, but also the founder of their lifelong learning ability development.

Second, it is the diversity of teaching methods. "There is a law in teaching, but there is no teaching method", so each teacher has his own unique teaching methods. However, when the 
ecological factors in teaching ecosystem change, teaching methods should also be changed. For example, when one of the subjects of the teaching - the students change, teachers should adopt different teaching methods. When the teaching environment changes, teachers should change teaching strategies.

Third, it is the openness of teaching content. The education ecosystem is a system of changing and growing. With the growth of knowledge and the improvement of personality, the teaching content should be changed with the development of the times. Therefore, the teaching content should not only adhere to the textbook, but it should be closely linked to the pulse of the times showing the characteristics of the open sea. The teacher should be a wise man in the classroom and be good at integrating knowledge and life. Teachers should cultivate students' noble quality of living and learning.

\section{The Design of College English Flipped Classroom Teaching Mode from the Perspective of Ecology}

Flip the classroom will explain the contents of the teacher's class before the class to allow students to learn to watch independently and the activities related to knowledge internalization are mentioned in the class. There is a lot of time in class for teachers to help students to solve the problems encountered in self-study before class, as well as the exchange and discussion between students and teachers and students and students. Professor Robert Tallbert in the United States in the application of multi course teaching used "flipped classroom" model and summed up the "flip classroom" implementation of the structural model as shown in Figure 1.

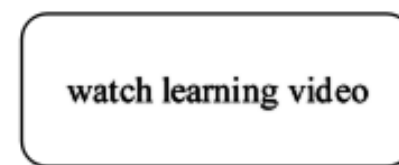

before class

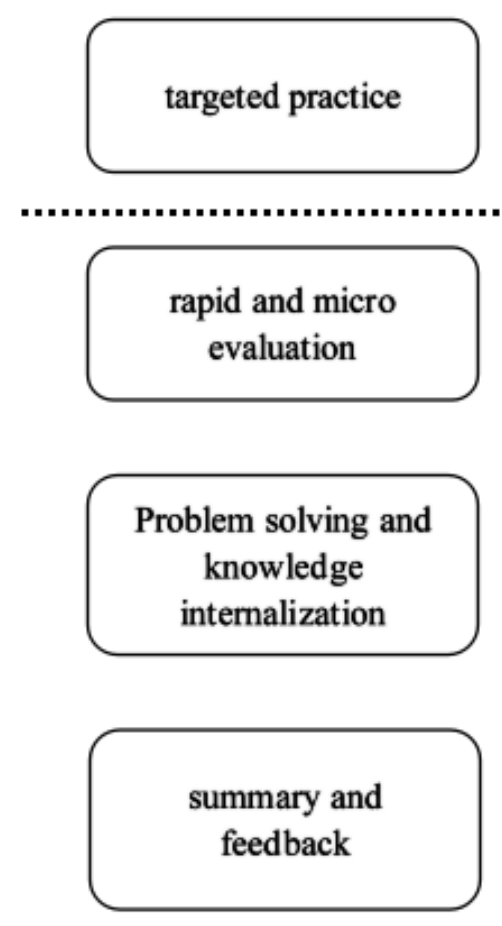

Fig.1 Flipped Classroom Structure

Pre-class teaching design. Teacher: first of all, teachers should choose suitable reading 
materials. According to the survey, many students think that the content of the textbook is too old and too boring to stimulate their enthusiasm and interest in reading. Therefore, the materials chosen by the teachers should keep pace with the times and be interesting. At the same time, the length of context book should not be too long. The key to the application of the "flipped classroom" model in reading classes is to allow students to read in class. The too long article will affect the reading effect and the activities of the classroom. Then, the teacher makes teaching video according to the selected materials. According to the content of the number, teacher can make one or more videos and each video is generally about 15 minutes. These videos include the following: the purpose and requirements of reading, as well as the key points; the use of new words and phrases to explain the relevant focus on grammar knowledge with the meaning of the sentence and the structure of the article and the reading methods. By watching the video, students can basically solve the language problems and have a certain understanding of the content and structure of the reading material.

Students: students complete the information to read and watch the video with understanding the content and requirements of the video; they also organize and analyze some of the key points of interest. For the content can not be understood, you can communicate with the students through independent learning platform or with other communication tools. They can also ask questions to teachers in the classroom and they should complete the task before class activities.

Teaching design in class. The purpose of reading is to reach the advanced level of judgment, which includes a number of information gathering and feedback activities. Among them, the collection, review, analysis and debate of relevant information are dominant. To achieve this level, students have to read in class and discuss it carefully. For example, a teacher may ask students to read, write, or read and write. Students through the course of skimming and watching video has basically solved the problem of language, so the teacher can let the students in the classroom while reading or writing after reading. The content should be helpful for the students to understand the meaning of the text and improve their reading skills. For example, teachers let the students find out the important details and the connection with the theme of the article and the importance of the plot and the relationship between the characters and so on. Careful study is one of the ways to cultivate the students' thinking skills.

At the beginning, the teacher organized the students to study and demonstrate the model. After reading a clip, the teacher can ask the students to discuss the topic, the words and the structure of the article; they also allow them to relate what they read in their lives and what you have learned before or what was discussed in class. Then, teachers organize students to review and analyze the content of reading. The teacher comments on the best comments so that students can figure out what kind of comments are valuable. These activities should be done in class so that students can get feedback in time. Through demonstration, students can study more independently.

On the basis of reading, teachers can organize students to study in a cooperative way. Students can group and study according to their favorite clips. Then, they communicate with other groups of students and discuss the comments of other students. In this way, it is easy for students to understand the way of reading, discussion and analysis. Cooperative study is conducive to the development of class discussions, which is beneficial for students to deeply analyze the parts of their interests. It is helpful to cultivate students' ability of empathy, which is a kind of ability to put oneself in another's position, so as to realize and understand the feelings of others.

Summary and consolidation after class. Teacher: after the end of a reading class, teachers should summarize and sum up the problems encountered by the students in the classroom. Through the online learning platform and timely feedback to students, teachers point out limits of the students in the areas of reading. 


\title{
Reflection on the Teaching Mode of College English Reversal from the Perspective of Ecology
}

It Increased the Burden on Teachers and Students to Some Extent. In order to apply the flipped classroom model to reading, Teachers should choose the material that can stimulate interest in reading and is appropriate difficulty before class. They should make videos for students to study before class. In class, teachers should not only solve the problems of students and give guidance, but also organize and design activities that can help students to participate actively. Teachers should understand the learning situation and learning effect, which is a huge challenge for teacher's time, energy and ability. The students should also have a strong self-learning ability to adapt to this model. Coupled with the need to take up a lot of their spare time to study, some students think that this model is their extra burden.

It should not only pay attention to the class reading and ignore the extracurricular reading. The key to the application of the flipped classroom model in College English reading teaching is let the students read deeply in class. However, the amount of reading time and reading is limited. To improve students' reading ability, it is also important to read a lot after class. A large amount of reading can lay a solid foundation for the students and cultivate the sense of language, which also helps them understand the knowledge in various fields and the students' autonomous learning ability can be improved. Therefore, extra-curricular reading can not be ignored.

Students should be encouraged to take an active part in class activities. Most of the students have been accustomed to the teacher in the classroom cramming "mode and passive learning. Therefore, some measures should be taken to actively participate in classroom activities. For example, we want to incorporate the student's classroom performance into the overall performance of the course.

\section{Summary}

From the perspective of ecology, the college English flipped classroom teaching mode, to some extent, serves the disadvantages of traditional college English reading class. In this model, the teacher asked the students to read carefully, analyze deeply and produce empathy. By allowing students to read in the classroom, students' reading consciousness is greatly improved. Gradually, they can form good reading habits, that is, fast reading before class, careful study in the classroom, and finally to analyze and form a complex point of view. However, each model has its drawbacks. The teachers should pay attention to the strengths and weaknesses in the implementation of the flipped classroom so as to improve the students' English reading ability.

\section{Acknowledgement}

\author{
Subject source: The 2016 Heilongjiang Educational Committee Planning Program \\ Subject name: The Construction and Effective Implementation of College English Flipped \\ Classroom from the Perspective of Ecology \\ Project number: GJC1316018
}

\section{References}

[1] Yang Beiyi. The Ecological Construction of College English Flipped Classroom[J]. Contemporary Education Forum, 2016, (04): 106-112.

[2] Li Jingnan, Wu Zhongjie. Practice and Reflection on College English Flipped Classroom[J]. Chinese Foreign Language, 2015, (06): 4-9.

[3] Zhang Jie, Li Ke, Du Xiao. Flipping College English Classroom: A Cool Thinking 
Based on the Current Situation Survey[J]. Modern educational technology, 2015, (07): 68-74.

[4] Li Yanping. Construction of Graded English Teaching Model Based on Flipped Classroom[J]. Global Education Outlook, 2015, (06): 113-119.

[5] Wei Dongxin. Strategy of College English Teachers to Flip the Classroom[J]. Education exploration, 2014, (12): 37-39.

[6] Cui Yanhui, Wang Yi. Flipped classroom and its application in College English teaching[J]. Chinese audio-visual education, 2014, (11): 116-121. 